\title{
Cluster as a key factor for sustainable development of the region
}

\author{
Elza Mantaeva \\ Kalmyk State University named after B.B. Gorodovikov, \\ Institute of Management and Law \\ Elista, Russia \\ mantaeva08@yandex.ru
}

\section{Inna Slobodchikova}

Kalmyk State University named after B.B. Gorodovikov, Institute of Management and Law

Elista, Russia

slobodchikova-iv@yandex.ru

\author{
Victoria Goldenova \\ Kalmyk State University named after B.B. Gorodovikov, \\ Institute of Management and Law \\ Elista, Russia \\ goldnova-vs@yandex.ru
}

\author{
Aisa Mantsaeva \\ Kalmyk State University named after B.B. Gorodovikov, \\ Institute of Management and Law \\ Elista, Russia \\ amancaeva@yandex.ru
}

\begin{abstract}
This study investigates the opportunities for creating a science and education cluster using the imitation modeling in the period of transition to a sustainable development of the region. As a result, this cluster may benefit the economy of the region and play a key role in fostering the increase of the GDP, salary, the level of employment, the number of highly qualified employees, as well as the volume of innovative goods and services.
\end{abstract}

Keywords- sustainable development, regional economy, science and education cluster, imitation modeling

\section{INTRODUCTION}

An increasing variety of research indicates that modern economic development causes the increase of human impact on the environment. The globalizations of the world economy, including international cooperation, scientific and technological progress, and innovative technologies aggravate the contradictions between economic and environmental interests. The problem of sustainable development of regions is now thoroughly on the agenda. This poses a common dilemma in choosing the right approach to pursue in overcoming the effects of the international economic crisis. Sustainable development is directed toward simultaneous solution of diverse and largely contradictory problems of economic growth, but the quality of the environment is maintained to meet the requirements of ecologists and the community. In recent years, deep attention was attracted to the regional dimension of the concept of sustainable development and to the process of creating and developing clusters. Considerable attention has been directed toward the development of clusters in regional economy due to positive experience of clusters in the developed countries. Studies suggest the value of extending the process in the direction of clusters' development and their outcomes into the wider public sphere. There is a tendency to consider cluster as a necessary factor and an essential part of the development strategy in the world economy. Environmental and social problems cause an increasing interest in applying clusters within the context of sustainable development.

The aim of the study is to analyze the role of clusters in regional economy using imitation modeling within the transition to the concept of sustainable development.

\section{MAterials AND Methods (Model)}

The methodological basis of the investigation is a systematic approach to studying the processes of clustering regional economic systems and imitation modeling in conditions of transition to sustainable development. To conduct research, authors used various scientific methods. These include: induction, review of economic and statistical sources, analogies, generalizations and logical method of research.

\section{RESULTS AND DISCUSSION}

A.

Sustainable development is a methodological concept that describes the transformation of modern socio-economic system. Its essence is the recognition of the organic nature of the development of society and nature with the comprehension that the world is a living organic thing.

Sustainable development is typically taken to mean that the well-being of the current generation should not be advanced at the expense of future generations. A more precise definition of sustainable development was given by the American scientist, former World Bank economist J. Daley, 
who understands sustainable development as a progressive social improvement without economic growth which goes beyond the ecological possibilities of sustaining the life of the whole system. Growth refers to the increase, while development means improvement [1]. In the beginning, sustainable development meant ecological sustainability, but then concerns with the society became a part of sustainability debate. At present, the concept of sustainable development has five dimensions: political, environmental, economic, social, and international.Необходимыми участниками любого кластера должны являться четыре экономических субъекта: предприятия, государственные органы власти, образовательные или исследовательские учреждения, а также финансовые учреждения.

Any cluster consists of four economic modalities: enterprises, public authorities, educational or research institutions, as well as financial institutions. The advantages of clustering the regional economy include economic effects leading to higher indicators of productivity of clusters, fostering their innovation activity; creation of favorable conditions for the creation of new enterprises due to the opportunities for easier access to suppliers, qualified personnel, scientific and educational centers and other sources of necessary resources; saving of production costs due to the effect of "economies of scale"; as well as the provision of special, preferential terms for the companies of the cluster that promote the launch of new types of production and products.

Legislation provides tools to allow flexible financing of activities aimed at the effective development of clusters. "Methodological recommendations for implementing cluster policy in the constituent entities of the Russian Federation" is the main document regulating the rules for the allocation of funds from the federal budget in order to give state support for the companies of the cluster participants and to provide the opportunity to obtain subsidies on a competitive and transparent basis for various projects. [2]

The cluster policy of the region should be implemented within the framework of the socio-economic development strategy of the region under the programs that can have a positive impact on the economy of the region and contribute to: the encouragement of the competitiveness of enterprises and the region; the strength of investment attractiveness of the region; the increase of investments in fixed assets; the increase of employment and reduction of unemployment; growth in the number of small and medium-sized enterprises; development of the region's infrastructure; the improvement of the level of education; the increase of labor productivity; ensuring higher rates of innovative development of the region; development of high-tech industries; improvement of the image of the region.

B.

The establishment and development of a scientific and education cluster can be favorable in the period of transition to sustainable development. This cluster is a set of interconnected institutions of higher and secondary vocational education linked to one industry and partner relations with other companies in this industry.
The process of creating this cluster requires significant funds and a preliminary quantitative assessment of feasibility and possible benefits as well as the use of a powerful mathematical apparatus and computer modeling tools.

This problem can be solved with the help of imitation modeling described as "the process of performing experiments with complex mathematical models of objects and systems existing in reality using a computer" [3]. In recent years, this method has become the main tool for comparing various options for managing solutions and finding the most effective option for economic systems at all levels.

In constructing an imitation model of any system it is necessary to conduct a preliminary study and to find regularities in the processes occurring in it in a formalized form (equations, inequalities, matrices, etc.). To detect these patterns we used a method of econometric modeling, that is the simple and multiple linear regressions. Their parameters are estimated using the method of least squares (OLS).

The main indicators included in econometric models were data taken from the official state statistics of the Kalmyk Republic for 2005 up to 2015:

- V1 - investment in fixed assets in RUB (millions);

- V2 - investment in fixed assets to the economic activity "Education" in RUB (millions);

- V3 - percentage of employment level;

- V4 - GRP (Gross Regional Product) in RUB (millions);

- V5 - monthly average nominal accrued salary of employees in organizations in RUB;

- V6 - education of qualified workers and employees in thousands of people;

- V7 - education of mid-level specialists in thousands of people;

- V8 - education of bachelors, specialists, masters in thousands of people;

- V9 - total spending for innovation (the sum of the values of the indicators "Internal spending for research and development" and "Spending for technological innovation") in RUB (millions);

- V10 - the volume of innovative goods, works, services in RUB (millions);

- V11 - used advanced production technologies in units;

- V12 -percentage of innovation activity of organizations;

- V13 - exports (the sum of the values of the indicators "With non-CIS countries" and "With the CIS countries") in USD (millions).

- We developed the patterns from the above-mentioned indicators with the assumption that the key processes determining the development of science and education are the following (Figure 1): 
- Investments in fixed assets to the economic activity "Education" increase the number and improve the quality of graduates of all specialties which leads to higher salary and the general level of employment in the region;

- On the other hand, part of this investment spent on research and development, technological innovation, and the purchase of advanced technology increases the level of innovation activity of organizations and the volume of innovative products;

- The growth of the volume of innovative products tends to affect indicators of exports and GRP of the republic. The higher level of employment has a direct impact on the growth of GRP, too.

In reality, however, not all hypotheses were confirmed, which led to some changes:

Firstly, investments of fixed assets to economic activity V2 "Education" affect V6 the number of education of qualified workers and V7 mid-level specialists, as well as V3 the level of employment in the region, but do not affect V8 the number of graduates.

Secondly, investment of fixed assets to economic activity V2 "Education" does not influence any of the variables characterizing the innovation activity of the region (V9, V10, V11, V12). However, the variable V9 "Total spending for innovation" is in direct linear dependence on V1 investments in fixed capital and in its turn affects V10 the volume of innovative goods.

Thirdly, V4 GRP depends on V3 the level of employment, $\mathrm{V} 10$ the volume of innovation products and V12 innovation activity of organizations.

Fourthly, we were not able to determine the linear dependencies between V13 exports on V10 the volume of innovative goods and on V11 the advanced technologies and other variables.

All mathematical dependencies in the form of regression equations are explained in Table 1 and the conceptual scheme of imitation model of a science and innovation cluster is shown in Fig.2. Econometric modeling was carried out in the application package SPSS 17.0 and imitation modeling was implemented in the soft package iThink v.9.1.3.

Some points should be noted about the variables V1, V8, $\mathrm{V} 11$ and V12. They are time series forecasted by the authors for the period of 2018-2022. The authors took into account the data of previous years and put them into the imitation model manually. All quantitative values are shown in the program codes of the models and can be corrected both in larger and in smaller side. The remaining variables are dependent and also represent the time series calculated by the program for the period of 2018-2022.

The results of the imitation model of the science and education cluster of the Republic of Kalmykia are divided into units for convenience and are depicted in Fig. 2.

This imitation model proved the practicability of creating and developing a science and education cluster in the Republic of Kalmykia in many ways:

- the increase of GRP by 1.2 times in five years, the increase of wages by 1.8 times, the increase of employment level by $3.2 \%$;

- an annual increase in the number of qualified workers and employees to 1,130 people, the increase of midlevel specialists up to 1,210 people;

- the increase in the volume of innovative goods and services by 1.3 times over five years and the increase of total investment in innovation by 1.7 times. 


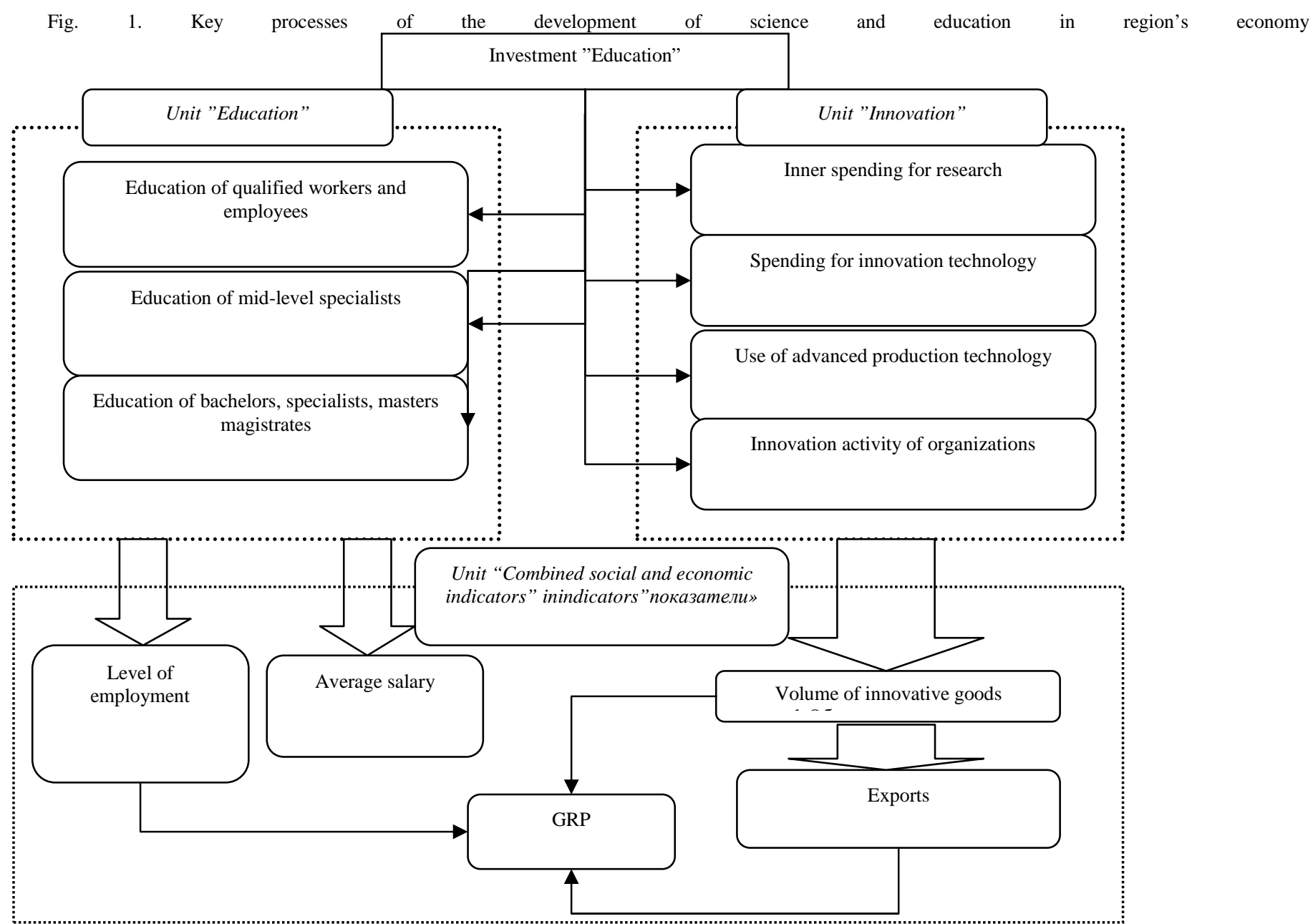


TABLE I. MATHEMATICAL DEPENDENCIES AMONG VARIABLES OF IMITATION MODELING

\begin{tabular}{|c|c|c|}
\hline Equation of regression & $\begin{array}{l}\text { Coefficient of } \\
\text { determination R2 } \\
\text { /Durbin-Watson } \\
\text { statistic (for multiple } \\
\text { regression) }\end{array}$ & Economic explanation of model options \\
\hline $\mathrm{V} 2=11.171+0.019 * \mathrm{~V} 1$ & 0.634 & $\begin{array}{l}\text { When each additional million rubles is invested in the region's } \\
\text { fixed capital, only } 19,000 \text { rubles are given to the education } \\
\text { sector }\end{array}$ \\
\hline $\mathrm{V} 3=55.3+0 / 018 * \mathrm{~V} 2$ & 0.712 & $\begin{array}{l}\text { Investments in education in the amount of } 1 \text { million rubles } \\
\text { increase the employment rate by } 0.018 \%\end{array}$ \\
\hline V6 $=0.854+0 / 00052 * \mathrm{~V} 2$ & 0.756 & $\begin{array}{l}\text { Investments in education in the amount of } 1 \text { million rubles } \\
\text { slightly increase the number of education of qualified workers }\end{array}$ \\
\hline $\mathrm{V} 7=0 / 754+0.00088 * \mathrm{~V} 2$ & 0.814 & $\begin{array}{l}\text { and employees and mid-level specialists by } 0.52 \text { and } 0.88 \\
\text { respectively }\end{array}$ \\
\hline $\mathrm{V} 5=7280.4+4924 * \mathrm{~V} 6+9109 * \mathrm{~V} 7+6785 * \mathrm{~V} 8$ & $0.737 / 1.982$ & $\begin{array}{l}\text { The increase in the education of qualified workers and } \\
\text { employees per } 1 \text { thousand people leads to an increase in salary } \\
\text { by an average of } 4,924 \text { rubles; the increase in the education of } \\
\text { mid-level specialists per } 1 \text { thousand people leads to an increase } \\
\text { in salary by an average of } 9,109 \text { rubles; the increase in the } \\
\text { education of bachelors, specialists, masters for } 1 \text { thousand } \\
\text { people leads to an increase in salary by an average of } 6,785 \\
\text { rubles. }\end{array}$ \\
\hline $\mathrm{V} 9=32.447+0.00356 * \mathrm{~V} 1$ & 0.691 & $\begin{array}{l}\text { When each additional million rubles is invested in the region's } \\
\text { fixed capital only } 3560 \text { rubles are spent for innovation in } \\
\text { average }\end{array}$ \\
\hline $\mathrm{V} 10=-7.89+0.11 * \mathrm{~V} 9$ & 0.662 & $\begin{array}{l}\text { The increase of general spending for innovation for } 1 \text { million } \\
\text { rubles leads to an increase of the volume of innovative } \\
\text { products, works and service by an average } 110,000 \text { rubles }\end{array}$ \\
\hline $\begin{array}{l}\text { V4=- } \\
19256.63+3738.53 * \mathrm{~V} 3+153.32 * \mathrm{~V} 10+361 . .88 * \mathrm{~V} 12\end{array}$ & $0.744 / 2.097$ & $\begin{array}{l}\text { The increase of employment level for } 1 \% \text { leads to an increase } \\
\text { of GRP by an average } 3738,53 \text { million rubles; the increase of } \\
\text { total spending for innovation for } 1 \text { million rubles leads to an } \\
\text { increase by an average } 153,32 \text { million rubles; the increase of } \\
\text { innovation activity of region's companies by } 1 \% \text { leads to an } \\
\text { increase of GRP by an average } 361,88 \text { million rubles }\end{array}$ \\
\hline
\end{tabular}




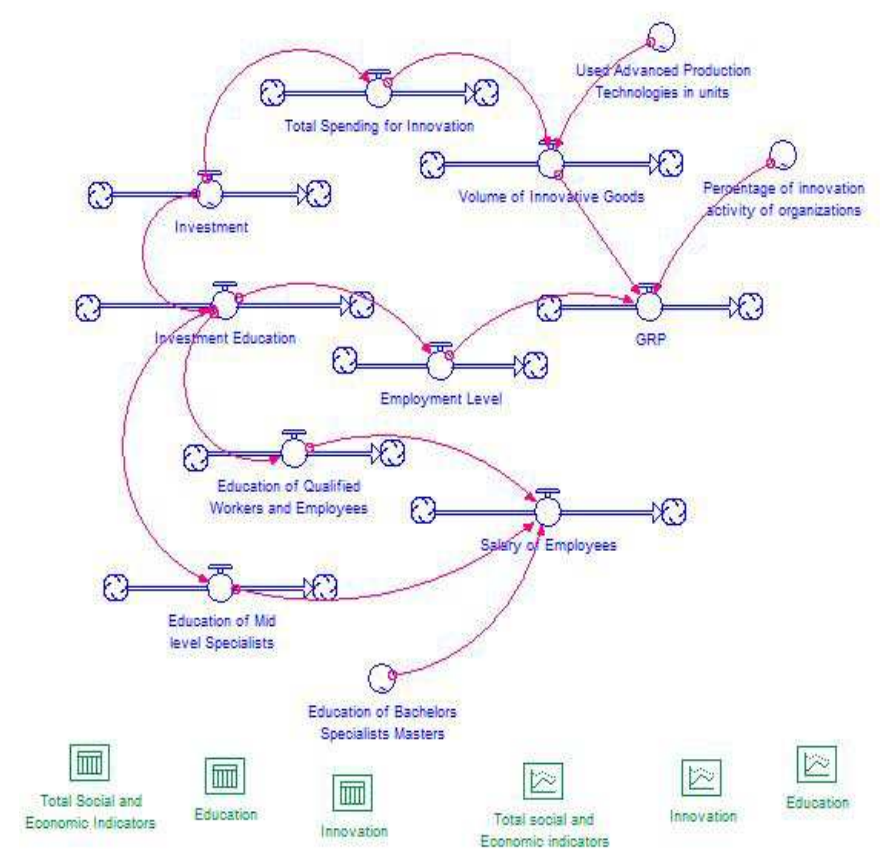

Fig. 2. Conceptual scheme of imitation model of a science and education cluster of the Republic of Kalmykia

\section{C.}

The Kalmyk State University named after B.B. Gorodovikov should play the leading role as the center for training and retraining personnel for science-intensive industries. It is the main source and channel for innovations providing companies with new competitive technology and developments. Alongside the Kalmyk State University the potential participants of the regional science and education cluster can be the Government of the Republic of Kalmykia; colleges of secondary vocational education; enterprises of various industries and sectors of the region's economy; course participants; public organizations; regional associations of employers; financial institutions; Chamber of Commerce and Industry; employment center.
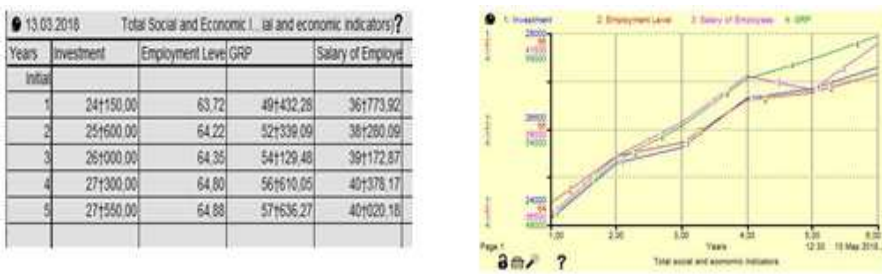

a) unit "Total social and economic indicators"

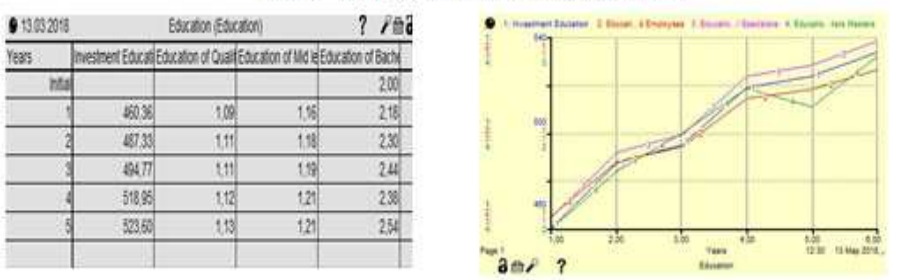

b) unit "Education"
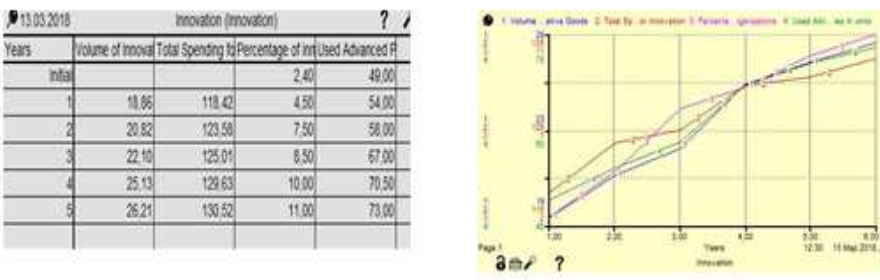

c) unit "Innovation"

Fig. 3. Forecast values of indicators of the Republic of Kalmykia in the condition of creating and development of a science and education cluster

The creation of a science and education cluster should be considered as the process of forming a structurally functional association of groups of companies with broader flows of resources of the Kalmyk University to a specific set of tasks. Their solution should specify some sequence or set of interconnected business processes that are implemented within the organizational chain from one participant to another.

The result of the activity should be a product that represents material and non-material value for regional authorities, economic agents, public institutions and the population as a whole.

Consideration to the creation, functioning, management and evaluation of the activity of the regional science and education cluster in a particular region should be based on project approach. In this case it is possible to consider the science and education cluster as a set of separate investment projects of innovative nature accumulated in the sphere of research and development, as well as educational activity and contributing to the implementation of the innovative potential, both for the residents of the cluster itself and for the region as a whole, through education of highly qualified innovationoriented personnel and the production of innovative scienceintensive products and services with a high proportion of added value. [4]

Creation efficiency and functioning of a science and education cluster can be evaluated in terms of the consequences for both the regional and national economies. Successful creation and functioning of the science and 
education cluster will contribute to the creation of jobs by small innovative entrepreneurship as well as to reduce the outflow of youth from the region, to increase employment in a science-intensive sphere; an increase in the volume of innovative goods and services, as well as an increase in gross regional products. It is on this basis that authorities at various levels often initiate actions to create and develop science and education clusters believing that "clusters serve as a source of driving forces that promote the growth of exports of innovative goods, works and services, and also attract investment, including capital with foreign participation "[5].

The science and education cluster should become a system of teaching, mutual teaching and self-learning tools in the innovation chain of science-technology-business based primarily on horizontal links within the chain.

One of the effective tools for achieving sustainable development of the region is rational combination and effective use of high scientific, technical, intellectual and industrial potentials of the university and the organizational and economic mechanisms and incentives aimed at the development of innovative entrepreneurship, including small and medium-sized enterprises working in the field of commercialization of science and technology. The sustainable development of the region can be achieved with the participation of three institutions: academic, corporate and state. Their joint policy within the science and education cluster should be aimed at the generation of entrepreneurship and business. Nowadays, the principle of the "triple helix" means joint entrepreneurial activity of business, the state and universities and is the basis for creating new territories for sustainable development. The university should play the key role in the science and education cluster.

\section{CONCLUSION}

The creation of a science and education cluster will positively affect the region's economy it will lead to the increase of the GRP, average salary, employment level, the number of qualified workers and employees, as well the volume of innovative goods and services. The Kalmyk State University will promote regional development and can also enhance its influence on sustainable development of the region. But sustainable development can be achieved if the university transfers innovation technology to the region's economy. The university will not limit its role to the education of specialists only. A regional university should play a key role as the driver of scientific and technological as well as socio-economic development of the region, as the center of forming and development of scientific, educational, production and innovation potential of the region. Regional universities are oriented to meet the needs of regional enterprises and organizations from different sectors of economy, authorities. These universities tend to implement the programs of higher and additional professional education preferred in this region and also they conduct research relevant in a specific region. In this regard, the creation of a science and education cluster can be an effective direction to meet the challenges of transition to sustainable development of the region.

\section{Acknowledgment}

The authors thank the Russian Fund of Fundamental Research for supporting the project № 17-46-080410 p_a.

\section{References}

[1] Glossary of terms and concepts of the "Green" economy, prepared by specialists and partners of the International Program "Sunny Stream". [Glossarii terminov i ponyatii «Zelenoi» ekonomiki, podgotovlennyi spetsialistami i partnerami Mezhdunarodnoi Programmy «Solnechnyi Potok»] URL: http://www.ecoteco.ru/library/magazine/1/economy/glossariy-terminovi-ponyatiy-zelenoy-ekonomiki/

[2] Methodological recommendations on the implementation of cluster policy in the constituent entities of the Russian Federation (signed by the Deputy Minister of Economic Development of the Russian Federation, A. N. Klepach, No. 20636-AK / D19 of 26.12.2008) [Metodicheskie rekomendatsii po realizatsii klasternoi politiki v sub"ektakh Rossiiskoi Federatsii]. URL: http: //economy.gov.ru/minec/activity/sections/innovations/development/doc1 248781537747/

[3] Zvyagin L.S. Use and relevance of simulation modeling for analytical purposes [Ispol'zovanie i aktual'nost' imitatsionnogo modelirovaniya $\mathrm{v}$ analiticheskikh tselyakh]. Economics and management: problems, solutions. Economic analytics, 2015, №12, volume 5, P. 79-87.

[4] Patrusheva, EG, Bolshakova, E.A. Evaluation of the economic efficiency of the regional innovation cluster / E.G. Patrusheva, E.A. Bolshakova [Otsenka ekonomicheskoi effektivnosti regional'nogo innovatsionnogo klastera ]. Management of economic systems. URL: http: //uecs.ru/index.php? Option $=$ com_flexicontent $\&$ view $=$ items $\&$ id $=3443$

[5] Tretyakova L.A., Gerasimov A.V. Monitoring and evaluation of the effectiveness of the activities of scientific and educational clusters [Monitoring i otsenka rezul'tativnosti deyatel'nosti nauchnoobrazovatel'nykh klasterov]. Management of economic systems: an electronic scientific journal, 2017, No. 9 (103). 